\title{
Techno-Economic Analysis of Biofuel Production Plants Producing Biofuels Using Fisher Tropsch Synthesis
}

\author{
Agate VEIPA ${ }^{1}$, Vladimirs KIRSANOVS ${ }^{2 *}$, Aiga BARISA ${ }^{3}$ \\ ${ }^{1-3}$ Riga Technical University, Institute of Energy Systems and Environment, Āzenes iela 12/1, \\ Riga, LV 1048, Latvia
}

\begin{abstract}
To address rising climate change problems, one significant task is reducing pollution in the transport sector by substituting fossil with biomass-based fuels. One of the potential production methods is by Fischer-Tropsch (FT) synthesis. Both gasoline and diesel types of fuel can be produced. For FT fuels a carbon containing feedstock is needed as an end product, it can be processed in multiple ways using various systems, however the main parts of production are biomass preparation and gasification, where afterwards clean-up of the synthetic gas is required. A liquid form from the syngas is achieved via FT synthesis, after which hydroprocessing is needed for separating naphtha, diesel, and lighter-molecularweight hydrocarbons or other components. For comparison of biofuel plants, the biomass of choice, production processes and end products were analysed, as well as economic feasibility of technologies, to determine whether the costs and investments required are reasonable for the possible outcome.
\end{abstract}

Keywords - Biodiesel; FT fuels; gasification; Latvia; second generation biofuel

\begin{tabular}{|ll|}
\hline \multicolumn{2}{|l|}{ Nomenclature } \\
FT & Fischer-Tropsch synthesis \\
REDII & Renewable Energy Directive 2018/2001/EU \\
EU & European Union \\
FCEV & Fuel cell vehicle \\
RES & Renewable energy resources \\
HVO & Hydrotreated vegetable oil \\
GHG & Greenhouse gas \\
TRL & Technology readiness level \\
TCI & Total capital costs \\
TOC & Total operating costs \\
I & Total income \\
CF & Cash flow \\
$\eta$ & Production efficiency \\
ROI & Return on investment \\
\hline
\end{tabular}

* Corresponding author.

E-mail address: vladimirs.kirsanovs@rtu.lv

(C)2020 Agate Veipa, Vladimirs Kirsanovs, Aiga Barisa.

This is an open access article licensed under the Creative Commons Attribution License (http://creativecommons.org/

licenses/by/4.0), in the manner agreed with Sciendo. 


\section{INTRODUCTION}

Due to concerns for climate and the impact from burning fossil fuels, the European Parliament and the Council announced a Renewable Energy Directive 2018/2001/EU (RED II). Its main goal is to provide countries with tasks and benchmarks to reduce emissions and negative impact on the environment. By 2030 in the transport sector at least $14 \%$ of biofuels have to be from renewable resources. However, only up to $3.7 \%$ of biofuels can be first generation, that are produced using food crops. This way European Union (EU) is stating the need to develop second generation biofuels, biofuels made from waste and non-food feedstock. By 2030 second generation biofuels should be $10.3 \%$ of total fuel consumption. With funding opportunities that can be provided by the EU, fuel companies are switching to alternatives and advancing biofuel production. With the existing potential for second generation biofuels and research activity it should be possible to progress technologies to where biofuels will have a price that can compete with fossil fuel prices [1]. That will help achieve EU goals for emission reduction in the transport sector [2].

In case of Latvia, the Renewable Energy Directive goal for 2020 (10\% share of biofuels in the transport sector) was not achieved. However, the share of biofuels is increasing mainly due to the minimum biofuel blend. Starting 2009 it was required that all diesel fuels and petrol 95 have at least $5 \%$ share of biofuels. In 2020 the share of biofuels in diesel fuels was increased to $7 \%$ and in petrol 95 to $10 \%$. First generation biodiesel and bioethanol are used in the mix for fossil fuels, it is either produced in Latvia or imported. The first obligatory minimum biofuel blend in all fuels accounted for a $2 \%$ increase in biofuel usage. According to the latest statistical data, the biofuel share in fuel consumption for 2018 was only $4.73 \%$ [3]. There are not any second-generation biofuel production plants in Latvia yet. Firstgeneration biofuels are produced in Latvia and are mostly made from rapeseed oil.

Until now, energy consumption in the transport sector is increasing every year. The total consumption of biofuels has increased by $19 \%$ between the years 2012 and 2018 . This could indicate that it will continue to grow, and it is therefore necessary to develop technologies, produce biofuels and use renewable energy resources (RES) at the highest possible rate. In 2018 , the transport sector consumed 15.0 TWh of energy, but the share of RES was only $2.54 \%$ of total fuel consumption. By the fuel consumption trend and targets, it is possible to calculate how much second-generation biofuels need to be produced or imported. By the observed increase in fuel consumption in the transport sector, fuel consumption is likely to increase to $16.9 \mathrm{TWh}$ per year in 2030 , where the required $14 \%$ share of fuel from RES, would be $2.36 \mathrm{TWh}$. And 2nd generation biofuels, such as Fisher-Tropsch (FT) fuel, should be consumed around $0.57 \mathrm{TWh}$. The end amount is multiple times lower, because second generation fuel usage is considered as double of its value, as declared by the Directive [4].

Second generation fuel production uses one or a combination of multiple conversion methods.

There are chemical, biochemical and thermochemical conversion methods that can produce such fuels as - cellulosic bioethanol, synthetic fuel, hydrotreated vegetable oil and biogas. Thermochemical processing technologies use the effects of temperature and pressure on the raw material to contribute to the chemical transformation of biomass into energy or chemical products. Thermochemical processes include gasification, pyrolysis and combustion. Gasification is one of the main steps to producing FT fuel, but pyrolysis is mainly used for 
making pyrolysis oil or biocrude. Based on chemical reactions and their ability to decompose the molecular structure of substances, conversion methods such as electrolytic hydrotreatment are used. It is used together with other technologies that use biological or thermal processes, but can also be used independently. Electrolysis is used for separating hydrogen and using it in vehicles called FCEV - fuel cell vehicle. Hydrotreating is a method used for achieving a hydrotreated vegetable oil (HVO), its structure is similar to biodiesel. Biochemical processes include the use of microorganisms and enzymes for the treatment of biomass. Fermentation is used for the splitting and conversion of different biological masses and is carried out at lower temperatures and pressures compared to thermochemical processes. The most commonly used biochemical processes are fermentation and anaerobic fermentation, where a gaseous or liquid substance is obtained as a final product. It is also important to use enzymatic hydrolysis in the production of biofuels if a liquid biomass is used. Most commonly fermentation is used for cellulosic ethanol and anaerobic fermentation for biogas. For the time being, second-generation fuel production methods are still mostly in the development phase and not widely available commercially. But thanks to a scientific progress, biofuels have great potential and can be used to reduce greenhouse gas (GHG) emissions in the transport sector.

One of the fundamental properties that can describe fuels is energy density. That and other parameters were compared among other similar types of fuels in Table 1. Fischer-Tropsch diesel has a density of between 760 to $790 \mathrm{~kg} / \mathrm{m} 3$, and an energy content of around $44 \mathrm{MJ} / \mathrm{kg}$, that is higher than those of fossil diesel and biodiesel. The cetane number is also higher, it varies from 55 up to 75 , where the number describes combustion speed which is related to ignition, similarly octane number works for gasoline and its alternatives. Another reason for FT diesel to be a suitable alternative is its low sulphur content, higher sulphur containing fuels can leave a negative impact on engines by causing corrosion. The use of FT fuel does not require any change by the user, it can be applied on all vehicles intended for diesel use. Further the author puts the focus on assessing FT fuel potential based on a techno-economic exploration method [5], [6].

\section{TABle 1. COMPARISON OF FUEL CHARACTERISTICS [5]}

\begin{tabular}{|c|c|c|c|c|}
\hline Fuel type & Energy content, $\mathrm{MJ} / \mathrm{kg}$ & Density, $\mathrm{kg} / \mathrm{m}^{3}$ & Cetane number & Octane number \\
\hline Gasoline & 42.7 & $715-765$ & - & $90-100$ \\
\hline Ethanol & 28.43 & 790 & - & 110 \\
\hline Diesel & 43.09 & $800-845$ & $50-55$ & - \\
\hline Biodiesel & 37.48 & 880 & 50 & - \\
\hline $\begin{array}{l}\text { Fischer-Tropsch } \\
\text { diesel }\end{array}$ & 44 & $760-790$ & $55-75$ & - \\
\hline
\end{tabular}

An important step in the production of synthetic biofuels is gasification, followed by synthesis of gas to obtain a liquid form during the transformation process. FT synthesis, which was discovered in the early 20th century, is widely studied and suitable for the given fuel. By the year 2020 there are still not many production plants for FT fuel, and most of them are pilot plants. Using the technology readiness level (TRL) method, different technologies can be evaluated. This categorisation system consists of 9 levels, where level 1 indicates that the technology is presented and tested in laboratory, while level 9 declares the successful operation of the technology. Thus, the readiness of FT technology is rated to be at level 6, which means that the system was built and tested in an artificial environment at the demonstration level. There are still barriers at production stages and there is a need to increase 
production efficiency and optimise synthetic gas yield. Existing plants have a capacity of between $8.7 \mathrm{GWh}$ to $1754 \mathrm{GWh}$ per year [7].

FT fuel production consists of biomass pre-treatment, gasification, synthetic gas (syngas) clean-up and FT synthesis. In the gasification process, heat is used to turn biomass to syngas, and its main components are carbon monoxide and hydrogen. There are three main types of gasifiers: up-draft, fluidized bed gasifier and the most widely used is down-draught gasifier. In the gasifier the following processes occur - drying, pyrolysis, combustion and reduction [8]. Often in this stage, as a side product, extra electricity and heat are generated which are forwarded to production stages that require this kind of energy. The excess electricity and heat can be sold for extra profit. After syngas has been produced via gasification, the syngas clean-up is necessary for higher quality biofuel. It makes a gas, with lower $\mathrm{H} 2 / \mathrm{CO}$ proportions, and that gives an advantage to FT synthesis, it produces less carbon dioxide, makes a low sulphur fuel with a very low aromatic content [9].

The aim of this study is to perform a techno-economic analysis of biofuel production plants producing biofuels using FT synthesis under conditions in Latvia.

\section{Methodology}

\subsection{Methodology Description}

To analyse the production of biofuels using the chosen technology, all stages of production are to be reviewed. The second generation, Fisher-Tropsch fuel production process is divided into four major subsystems: biomass pre-treatment, gasification, synthetic gas (syngas) cleaning and FT synthesis (see Fig. 1).

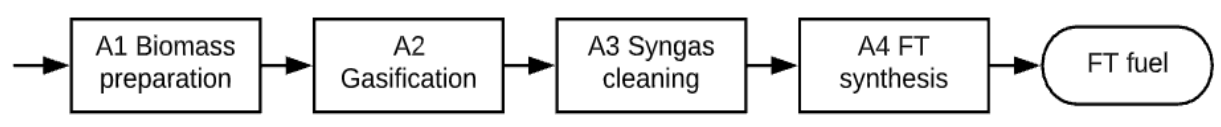

Fig. 1. FT fuel production steps.

For cost analysis, it is important to see each of the production stages and their consumption. In order to assess the costs of using innovative technology, literature data from other studies and real cases were examined. The appropriate data were selected and evaluated to fit the investigational system. Different production quantities will constitute different costs and revenues, so their values (in EUR) were extended to production amount of EUR/MWh, so that the results can be compared between studies.

It is necessary to look at the production scheme and the indicators that describe it - capital costs and production costs, raw material consumption and energy flow and income. To evaluate FT fuel production profitability, multiple indicators were used. The total capital costs consist mainly of necessary investments for production steps, as shown in Eq. (1).

$$
T C I=A 1_{i}+A 2_{i}+A 3_{i}+A 4_{i}+A 0_{i}
$$

where

TCI Total capital costs, EUR;

$A 1_{i} \quad$ Capital costs for biomass preparation, EUR; 
$A 2_{i} \quad$ Capital costs for gasification process, EUR;

$A 3_{i} \quad$ Capital costs for syngas cleaning, EUR;

$A 4_{i} \quad$ Capital costs for FT synthesis, EUR;

$A O_{i} \quad$ Other capital costs, EUR.

The total operating costs were also evaluated for each stage in Eq. (2).

$$
T O C=A 1_{o}+A 2_{o}+A 3_{o}+A 4_{o}+A 0_{o},
$$

where

TOC Total operating costs, EUR/year;

$A 1_{o} \quad$ Biomass costs, EUR/year;

$A 2_{o}$ Gasification process costs, EUR/year;

$A 3_{o} \quad$ Costs for syngas cleaning, EUR/year;

$A 4_{o}$ Costs for FT synthesis, EUR/year;

$A 0_{o}$ Other costs, EUR/year.

Income comes from all products sold. In this case, the main product is FT fuel, but in its production a side product can be electricity generation, as in Eq. (3).

$$
I=Q_{\mathrm{b}} \cdot P_{\mathrm{b}}+Q_{\mathrm{el}} \cdot P_{\mathrm{el}},
$$

where

$I \quad$ Total income, EUR/year;

$Q_{\mathrm{b}} \quad$ Amount of biofuels produced, $\mathrm{MWh} /$ year;

$P_{\mathrm{b}} \quad$ Biofuel price, EUR/MWh;

$Q_{\text {el }} \quad$ Amount of electricity generated, MWh/year;

$P_{\mathrm{el}} \quad$ Electricity price, EUR/MWh.

Annual cash flow is represented by the difference between annual income and TOC as shown in the Eq. (4).

$$
C F=I-T O C,
$$

where

CF Cash flow, EUR/year;

I Total income, EUR/year;

TOC Total operating costs, EUR/year.

The production process can also be characterised by the production efficiency as in Eq. (5), the ratio of the final product produced to the amount of biomass used. Comparing these values for different production plants represents the amount of biomass needed for fuel production.

$$
\eta=\frac{\dot{M}_{\mathrm{b}} \cdot L H V_{\mathrm{b}}}{\dot{M}_{\text {biomass }} \cdot L H V_{\text {biomass }}} \cdot 100,
$$

where

$\eta \quad$ Production efficiency, \%;

$\dot{M}_{\text {b }} \quad$ Amount of biofuel produced, tonnes/year; 

$\dot{M}_{\text {biomass }}$
Amount of biomass used, tonnes/year;
$L H V_{\mathrm{b}}$
Biofuel heating value, $\mathrm{kJ} / \mathrm{kg}$;
$L H V_{\text {biomass }}$
Biomass heating value, $\mathrm{kJ} / \mathrm{kg}$.

By accumulating annual cash flow, the payback period (PBP) could be calculated. PBP was used as an important indicator of profitability. Another indicator was return on investments (ROI), it was used to assess profitability over the production plants working time of 15-years.

$$
R O I=\frac{C F-T I C}{T I C} \cdot 100,
$$

where

ROI Return on investment, \%;

$C F \quad$ Total cash flow over the period of 15 years, EUR;

TCI Total capital costs, EUR.

With the developed methodology, it is possible to assess whether the production of biofuels will be economically justified. The ROI indicator is used to assess profitability.

\subsection{Data Collection}

In compiling existing research on fuel production possibilities, using Fischer-Tropsch synthesis, a methodology was developed to perform a case study in Latvia. The methodology is based on 16 studies. In order to compare studies and their results, their technological and economic characteristics and their values are necessary. The main data required from the studies for analysis and calculation are summarised in Table 2.

Table 2. Data About FT Fuel Production Collected From Studies

\begin{tabular}{lllll}
\hline Parameters & $\begin{array}{l}\text { Production capacity, } \\
\text { GWh/year }\end{array}$ & $\begin{array}{l}\text { Capital costs, } \\
\text { Million EUR }\end{array}$ & $\begin{array}{l}\text { Production costs, } \\
\text { Million EUR }\end{array}$ & $\begin{array}{l}\text { Total income, } \\
\text { Million EUR }\end{array}$ \\
\hline Swanson et al., 2009 [10] & 1308 & 227 & 72.0 & 146 \\
Swanson et al., 2009 [10] & 1754 & 277 & 58.2 & 165 \\
McEniy et al., 2014 [11] & 1492 & 305 & 71.6 & 143 \\
McEniy et al., 2014 [11] & 1492 & 305 & - & 71.3 \\
Mustafa et al., 2017 [12] & 37.0 & 24.0 & 4.4 & 4.8 \\
Li et al., 2015 [13] & 1217 & 398 & - & - \\
Dimitriou et al., 2018 [14] & 1655 & 407 & - & 147 \\
Dimitriou et al., 2018 [14] & 1750 & 422 & - & 155 \\
Cardoso et al., 2019 [15] & 260 & 81.1 & - & - \\
Zhu et al., 2011 [16] & 1050 & 318 & 72.6 & 124 \\
Michailos et al., 2017 [17] & 1607 & - & - & 57.0 \\
Ramirez et al., 2019 [18] & 189 & 61.0 & 11.1 & - \\
Rafati et al., 2017 [19] & 1622 & 367 & - & - \\
Neuling et al., 2018 [20] & 8.7 & 5.3 & 0.8 & - \\
Hamelinck et al., 2004 [21] & 1297 & 412 & - & - \\
Albrecht et al., 2017 [22] & 295 & - & 32.1 & \\
\hline
\end{tabular}




\section{Results}

The collected data from 16 studies represent factories of different production volumes and parameters. Total investment and production capacity vary, but reflect the approximate necessary costs for fuel production. The values were allocated to four steps following the production scheme established in the methodology. The average values from the studies are analysed further and represent an average production capacity of $1064950 \mathrm{MWh} /$ year. The main parameters are shown in Table 3.

TABle 3. Production Plant PARAmeters

\begin{tabular}{lll}
\hline Parameters & Unit & Average value \\
\hline Production capacity & $\mathrm{MWh} /$ year & 1064950 \\
Biomass usage & $\mathrm{MWh} / \mathrm{MWh}$ & 2.10 \\
Biofuel heating value & $\mathrm{MWh} / \mathrm{m}^{3}$ & 9.90 \\
Biofuel price & $\mathrm{EUR} / \mathrm{MWh}$ & 75.8 \\
\hline
\end{tabular}

Biomass usage was a calculated value representing the amount of biomass energy (MWh) needed to produce $1 \mathrm{MWh}$ of biofuel. This value varied from $1.38 \mathrm{MWh}$ to $3.42 \mathrm{MWh}$ of biomass per $1 \mathrm{MWh}$ biofuel, but in average was 2.10 .

\subsection{Capital Costs}

Capital costs were separated for designated production steps and other costs, that consist mainly of construction costs, planning and licences, with a few exceptions when there is an additional phase in the study's production steps. To analyse and compare the TCI between studies, the relative values were used (EUR/MWh) as shown in Table 4.

Table 4. Production Plant Capital Costs

\begin{tabular}{lll}
\hline Capital costs & Unit & Average value \\
\hline Biomass preparation & EUR/MWh & 22.6 \\
Gasification & EUR/MWh & 56.0 \\
Syngas cleaning & EUR/MWh & 43.0 \\
FT synthesis & EUR/MWh & 29.9 \\
Other costs & EUR/MWh & 73.7 \\
Total capital costs & EUR/MWh & 225 \\
\hline
\end{tabular}

By examining the four production steps and the breakdown of the investments in Table 4, it is possible to analyse each phase individually and other necessary investments. From the production stages, gasification is the most expensive. However, the other costs beside the production steps take up $32.7 \%$ of needed investments, as shown in Fig. 2. 


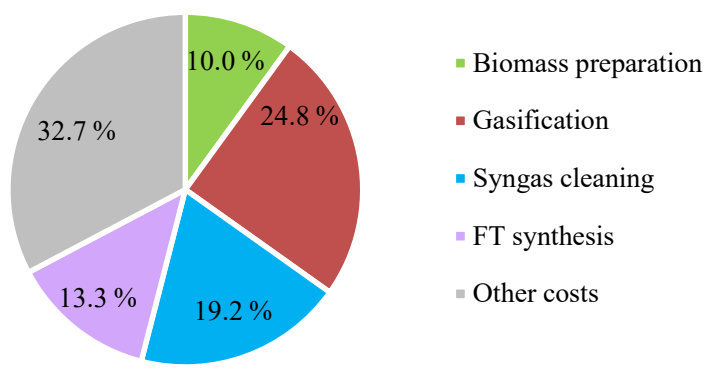

Fig. 2. Breakdown of capital costs.

\subsection{Operation and Maintenance Costs}

The production costs are also divided similar to production steps. The first step is considered to consist of biomass purchase, but the others are not divided into specific materials, they are simply costs associated with all the energy and material necessary for achieving their task. All the values were also taken relative to the production capacity, as shown in Fig. 3.

TABle 5. Production Plant Operating COSTS

\begin{tabular}{lll}
\hline Production costs & Unit & Average value \\
\hline Biomass costs & EUR/MWh & 26.5 \\
Gasification costs & EUR/MWh & 12.2 \\
Syngas cleaning costs & EUR/MWh & 1.53 \\
FT synthesis costs & EUR/MWh & 6.59 \\
Other costs & EUR/MWh & 23.6 \\
Total production costs & EUR/MWh & 70.4 \\
\hline
\end{tabular}

According to the data obtained, it can be concluded from studies that $46.6 \%$ of the annual TOC is composed of the purchase of raw materials or biomass. The second largest operating costs are maintenance, salaries and other variable costs not related to the separated production steps.

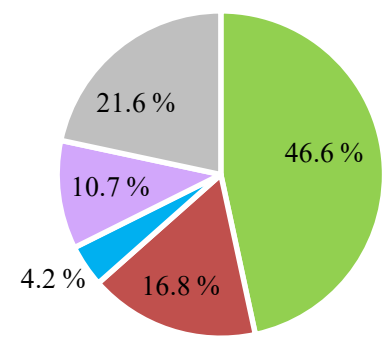

- Biomass costs

- Gasification costs

- Syngas cleaning costs

- FT synthesis costs

- Other costs

Fig. 3. Breakdown of production costs. 
A strong correlation was observed between production capacity and a number of binding parameters. Both TOC and TCI have a strong correlation to a change of production capacity, the determination coefficient $\left(R^{2}\right)$ being 0.738 and 0.740 , respectively. It was observed that larger production capacity resulted in lower TOC and TCI for a MWh of fuel produced.

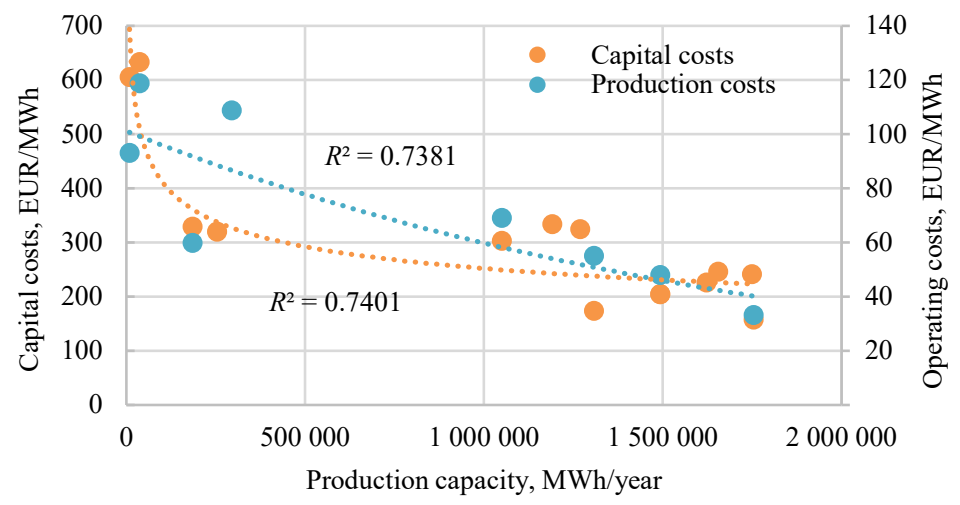

Fig. 4. Correlation between total capital and operation costs with plant production capacity.

\subsection{Incomes}

In the production of FT fuel as a final product, electricity and thermal energy can be obtained as a by-product. In most cases, it would be beneficial to use it for the plant itself, but in some cases, it was observed that surplus energy was produced and sold in order to obtain additional income. In only two cases, other by-products were also obtained.

TABle 6. Production Plant InCOME

\begin{tabular}{lll}
\hline Income & Unit & Average value \\
\hline Biofuels & MEUR/year & 92.4 \\
\hline Biofuel amount sold & $\mathrm{m}^{3} /$ year & 111899 \\
Biofuel price & EUR/m ${ }^{3}$ & 877 \\
\hline Electricity & MEUR/year & 4.27 \\
\hline Electricity amount sold & MWh/year & 64950 \\
Electricity price & EUR/MWh & 78.0 \\
\hline Other income & MEUR/year & 1.00 \\
\hline Total income & MEUR/year & 97.7 \\
\hline
\end{tabular}

By Eq. (5) the production efficiency was calculated and had a good correlation with production capacity, where larger production capacity meant higher efficiency. The payback period strongly correlates with production capacity with a $R^{2}$ of 0.87 , which means larger production capacity would result in a shorter PBP for the production plant. 


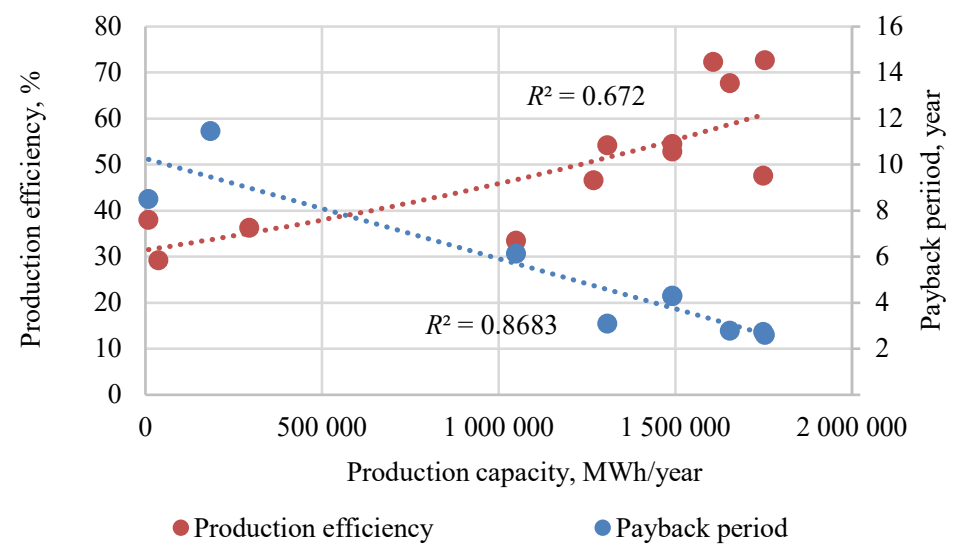

Fig. 5. Correlation between production efficiency, PBP and production capacity.

\subsection{Sensitivity Analysis}

A sensitivity analysis was done to see how multiple factors affect the payback period of a biofuel production plant. First a cash flow was made for a production plant with a capacity of $1000000 \mathrm{MWh} /$ year. The costs and investments for the factory were made according to data from research and regression equations between correlating parameters. For the reference values, the PBP was 7.3 years. In the calculations for the cash flow assumptions were made for the price of biofuels, electricity and biomass, thus an analysis was done on how their price change would affect PBP. Price and cost values were varied between $-30 \%$ and $+30 \%$ of their original value, as shown in Fig. 6.

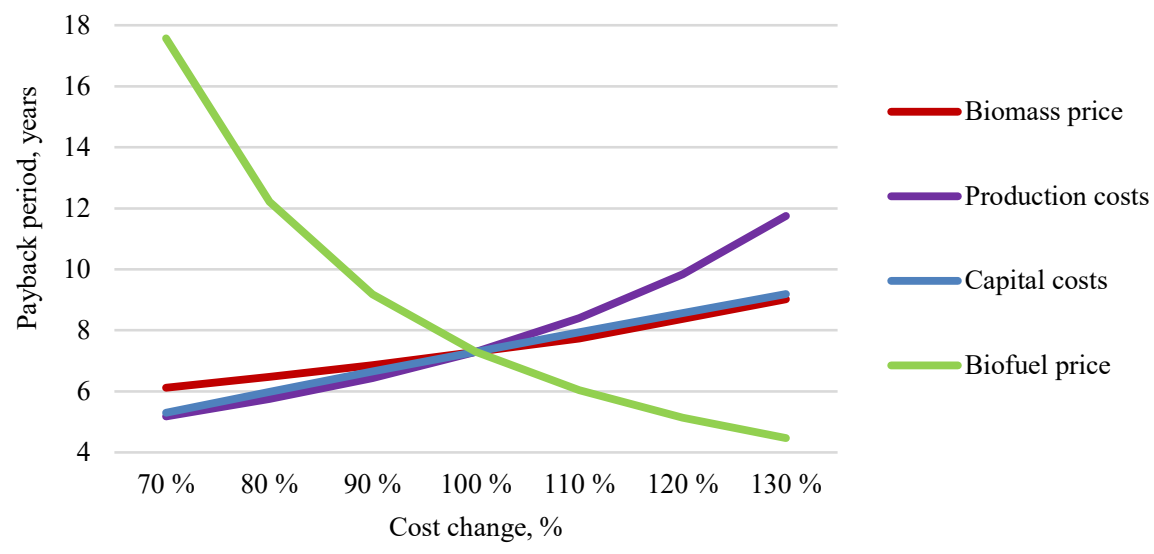

Fig. 6. Sensitivity analysis for payback period.

The change in biomass price increases or decreases the PBP only by around 1.5 years, as biomass is a part of production costs. However, production costs also include catalysts and electricity prices, but they were not calculated separately. Thus, by changing the total production costs, the PBP can change in a range of 7 years. The biofuel price affects the PBP 
the most, a $30 \%$ decrease in price can extend PBP by 10 years, while an increase of $30 \%$ reduces PBP by 3 years.

\subsection{Cash Flow Analysis - Case Study}

In cooperation with the cogeneration station "Zeiferti" in Latvia, Jaunolaine, the possibility of upgrading the station and integrating biofuel production was analysed. The biomass used at the plant is woodchips and its used to produce syngas using gasification. These production stages for syngas coincide with production of the FT fuel. The station uses syngas and produces $49.7 \%$ thermal energy and $50.3 \%$ electricity, with a total heat and electricity production of $2736 \mathrm{MWh} /$ year. The investments needed to operate such a station were 585000 EUR. Information was obtained on the station's capital and production costs. At present, the electricity sold from the station is allocated with a feed-in tariff. Thus, thanks to the additional income from selling electricity, the feed-in tariff ensures a profitable production.

Since the station was granted operational permits in 2015 , the year 2021 will be adopted as project year 7. Seven scenarios (base and six alternative scenarios) were considered for the station's operation options under different conditions by which the cash flows were created. Four cases are based on the existing cogeneration plant, while the remaining three are a construction of a new plant, assuming that its TOC and TCI correspond to the cogeneration station reviewed. The calculations assumed biomass cost inflation of $1.0 \%$, while for heat and electricity its $1.5 \%$, total inflation of $2.0 \%$, while for biofuels its $3.0 \%$. The interest rate on capital investment loan was taken as $10 \%$. The conditions for the scenarios are the following:

1. Base scenario 1 - all syngas is used for energy production in the cogeneration station. The feed-in tariff is added in electricity tariffs.

2. Scenario 2 - all syngas is used for energy production in the cogeneration station. The feedin tariff is stopped starting year 7 .

3. Scenario 3 - the station invests in biofuel production and begins the work in year 7 . All produced syngas is used for biofuel production.

4. Scenario 4 - the station invests in biofuel production and begins the work in year 7 . All produced syngas is used for biofuel production. The government funds 20 EUR/MWh for biofuel production.

5. Scenario $5-$ a new biofuel production plant is built (investments consist of gasification plant TCI and capital costs for FT synthesis).

6. Scenario $6-$ a new biofuel production plant is built (investments consist of gasification plant TCI and capital costs for FT synthesis). The government funds 20 EUR/MWh for biofuel production.

7. Scenario $7-$ a new biofuel production plant is built (investments consist of gasification plant TCI and capital costs for FT synthesis). Biomass is purchased with a $25 \%$ discount.

When switching to fuel production, it was calculated that the station could produce $2067 \mathrm{MWh} /$ year of fuel $\left(208622 \mathrm{~m}^{3} /\right.$ year $)$. In order to switch to the production of biofuels at the station, it was assumed that 132000 EUR of capital costs were needed, and total production costs would be 16600 EUR. While building a new station, TCI would be 723000 EUR. These values were obtained according to the analysed studies, where FT synthesis represented $13.3 \%$ of the total investment. The accumulated cash flows for $1^{\text {st }}$ to $4^{\text {th }}$ scenario are shown in Fig. 7. 


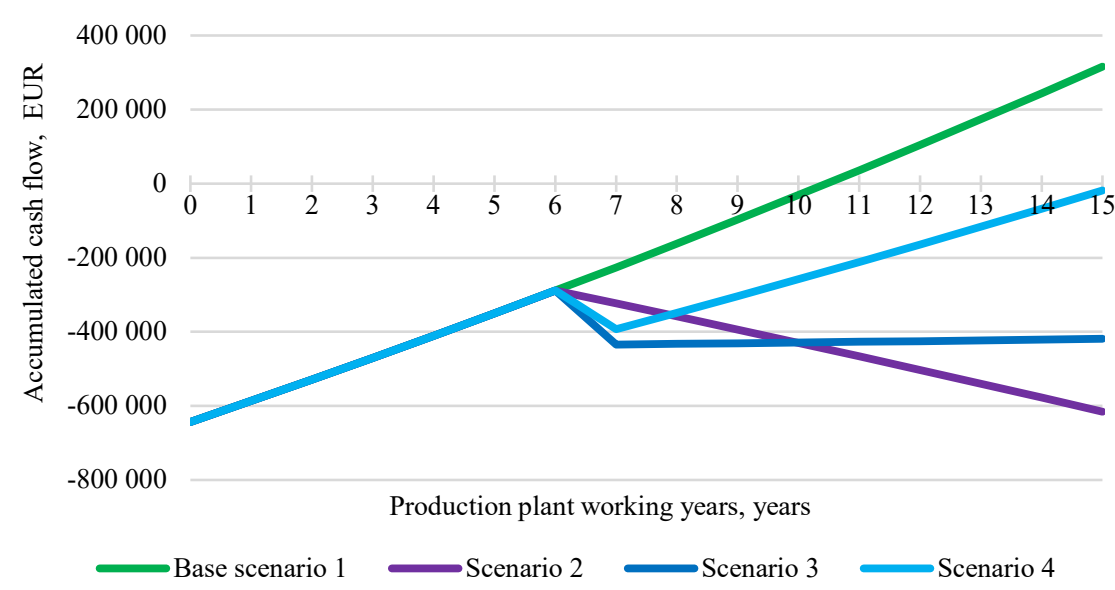

Fig. 7. Accumulated cash flows for scenarios 1-4.

The target is the production of biofuels, so it should be noted that scenarios 1 (base) and 2 reflect the production of syngas at the overviewed station for the production of heat and electricity.

ROI was calculated for all the scenarios to evaluate their profitability over the 15 -year period by using Eq. (6). In the case of the base scenario, this value is positive, $49 \%$. But the scenario 4 shows that, without the financial support in the form of a feed-in tariff starting year 7 will result in insolvency. A similar situation was observed with fuel production, without financial support, the fuel production will not pay off. In the scenario 3, biofuels are produced, but the ROI is a negative value, which means that capital costs in 15 years do not pay off and such a scenario may be considered economically unreasonable. On the other hand, if a financial contribution of $20 \mathrm{EUR} / \mathrm{MWh}$ could be subsidized, the PBP would be 15.4 years and the ROI $20 \%$ (scenario 4). When comparing the scenario 4 to the base scenario, it shows that biofuels can be produced with investments of 132000 EUR, and the PBP would be set off for another 4.9 years.

In the case of the $5^{\text {th }}$ to $7^{\text {th }}$ scenarios, the total capital costs are 723000 EUR. TCI consist of the cogeneration stations TCI and the additional investments for FT synthesis. For the construction of a new production plant, the repayment time period is 20.5 years and therefore has a negative ROI over 15 years $-39 \%$. Assuming it is possible to obtain funds from the government in the amount of $20 \mathrm{EUR} / \mathrm{MWh}$ for the production of biofuels, then as the $6^{\text {th }}$ scenario in Fig. 8 shows, it is apparent that the PBP is 10.9 years, and ROI is the highest, $57 \%$. If a $25 \%$ discount is applied to the purchase of biomass, the PBP is 15.0 years and after these 15 years, the investment has been returned with ROI of $0.2 \%$. 

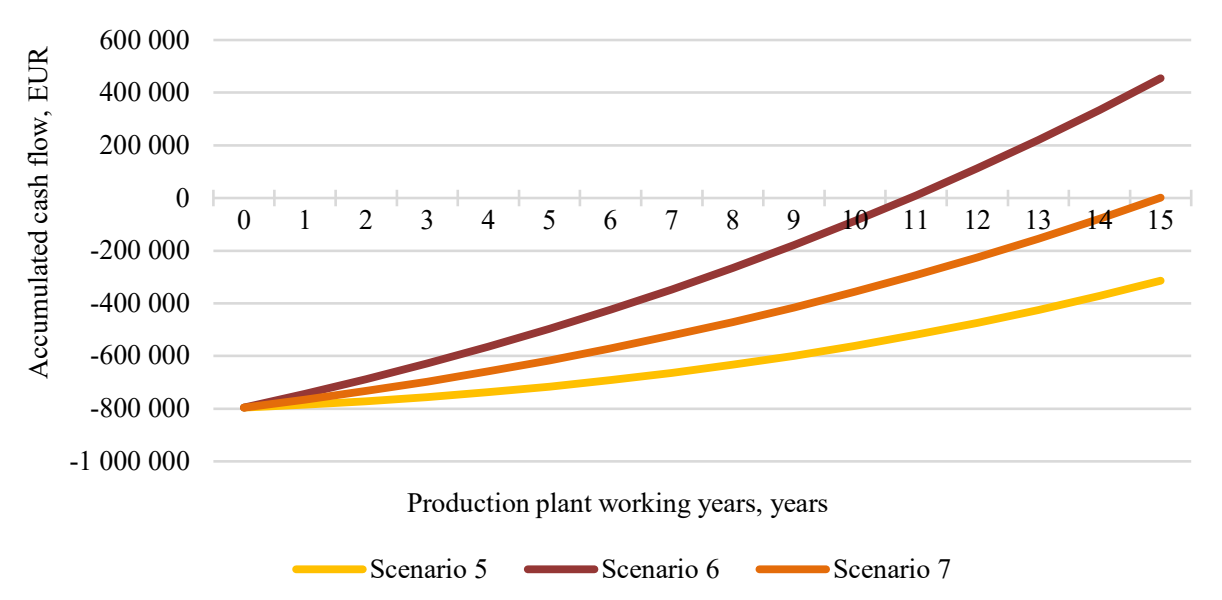

Fig. 8. Accumulated cash flow of scenarios 5-7.

Only scenarios 4 and 6 result in a positive ROI indicator for fuel production $-20 \%$ and $57 \%$, respectively. Both of these scenarios include the necessary financial support.

\section{Conclusions}

According to the RED II Directive, $2^{\text {nd }}$ generation biofuel use should be increased to $7.0 \%$ by 2030 . There are a number of technologies for the production of second-generation biofuels. One of the more prospective technologies in Latvia would be the production of a synthetic fuel called Fischer-Tropsch fuel using biomass gasification. Several biomass gasification plants are already operating in Latvia, where biofuel production could be integrated.

Based on the developed methodology, it is possible to carry out a techno-economic analysis for FT fuel production to assess the profitability for the production of biofuels. 16 worldwide studies of FT fuel production were investigated, data on capital costs, production costs, income, raw materials and product prices were collected. Based on the parameters with strong correlations, it was concluded that the larger the production capacity of the FT fuel, the lower the relative (EUR/MWh) production costs and capital investments. Similarly, larger production capacity meant a shorter time to repay the investments and a higher production efficiency. The acquisition of biomass accounts for the largest share of production costs $46.6 \%$.

By results of the sensitivity analysis, it appears that the price of sold biofuels affect the payback period the most. With the price of biofuels falling from $100 \%$ to $70 \%$, the PBP for the production would increase from 7.3 years to 17.6 years. In contrast to the increase in the price of biofuels from $100 \%$ to $130 \%$, the PBP would be reduced from 7.3 years to 4.5 years.

A number of scenarios were analysed for the production of FT fuel in Latvia, both by integrating into an existing gasification cogeneration plant and by building a new plant. From the first 4 scenarios examined, the best profitability indicator was for the baseline scenario when the production of syngas is used in electricity and heat generation using the feed-in tariff subsidies. However, without the support of the feed-in tariff, economic producers are 
lower than those with biofuel production. Looking at three scenarios for building a new FT fuel production plant in Latvia, it was concluded that the return on investment without financial support would have a ROI of only $0.2 \%$ and pays off over 20 years. With the aid of $20 \mathrm{EUR} / \mathrm{MWh}$ for biofuels production, however, the PBP would be reduced to 11 years and the ROI would be $57 \%$.

The results show that without an additional support mechanism, fuel production will not be profitable enough to attract investors and repay investments at this moment at Latvia. It is therefore necessary to obtain government support in order to promote the production of second-generation biofuels and the reduction of GHG emissions.

\section{ACKNOWLEDGEMENT}

This research is funded by the Ministry of Economics of the Republic of Latvia, project "Sustainable and renewable transport policy formulation in Latvia”, project No. VPP-EM-2018/AER_2_0003.

\section{REFERENCES}

[1] Groschopf W., Fuerst E., Kummer S., Herold D. Identifying carbon reduction potentials in road transportation: Creating a carbon-tracking tool for small and medium enterprises (SMEs). Environmental and Climate Technologies 2019:23(1):98-110. https://doi.org/10.2478/rtuect-2019-0007

[2] European Union. Legislation. Official Journal of the European Union 2009:L 140(52).

[3] Cabinet of Ministers. Pastiprinās degvielas kvalitātes kontroli un palielinās minimālā biodegvielas piejaukuma apmēru 2019 (Fuel quality control will be strengthened and the minimum biofuel blend will be increased in 2019) [Online] [Accessed 10.01.2020]. Available: https://www.mk.gov.lv/lv/aktualitates/pastiprinas-degvielas-kvalitates-kontroliun-palielinas-minimala-biodegvielas (in Latvian)

[4] Eurostat. Final energy consumption in transport sector [Online]. [Accessed 25.02.2020]. Available: https://ec.europa.eu/eurostat/tgm/refreshTableAction.do?tab=table\&plugin=1\&pcode=ten00124\&language=en

[5] Takeishi K. Dimethyl ether (DME): a clean fuel/energy for the 21 st century and the low carbon society. International Journal of Energy Environment 2016:10(1):238-242.

[6] Müller-Langer F., Majer S., Keeffe S. O. Benchmarking biofuels - a comparison of technical, economic and environmental indicators. Energy, Sustainability and Society 2014:4:20. https://doi.org/10.1186/s13705-014-0020-x

[7] Bezergianni S., Dimitriadis A. Comparison between different types of renewable diesel. Renewable and Sustainable Energy Reviews 2013:21:110-116. http://dx.doi.org/10.1016/j.rser.2012.12.042

[8] Klavins M., Bisters V., Burlakovs J. Small Scale Gasification Application and Perspectives in Circular Economy. Environmental and Climate Technologies 2018:22(1):42-54. https://doi.org/10.2478/rtuect-2018-0003

[9] Diyoke C., et al. Modelling of down-draft gasification of biomass - An integrated pyrolysis, combustion and reduction process. Applied Thermal Engineering 2018:142:444-456. http://dx.doi.org/10.1016/j.applthermaleng.2018.06.079

[10] Swanson R. M., et al. Techno-Economic Analysis of Biofuels Production Based on Gasification. Technical Report NREL/TP-6A20-46587, 2010. https://doi.org/10.2172/994017

[11] McEniy J., O'Kiely P. 11-Developments in grass-/forage-based biorafineries. Advances in Biorefineries. Woodgead Publishing, 2014:335-363. https://doi.org/10.1533/9780857097385.1.335

[12] Mustafa A., Calay R. K., Mustafa M. Y. A Techno-economic Study of a Biomass Gasification Plant for the Production of Transport Biofuel for Small Communities. Energy Procedia 2017:112:529-536. https://doi.org/10.1016/j.egypro.2017.03.1111

[13] Li Q., Zhang Y., Hu G. Techno-economic analysis of advanced biofuel production based on bio-oil gasification. Bioresource Technology 2015:191:88-96. https://doi.org/10.1016/j.biortech.2015.05.002

[14] Dimitriou I., Goldingay H., Bridgwater A. V. Techno-economic and uncertainty analysis of Biomass to Liquid (BTL) systems for transport fuel production. Renewable and Sustainable Energy Reviews 2018:88:160-175. https://doi.org/10.1016/j.rser.2018.02.023

[15] Cardoso J., Silva V., Eusébio D. Techno-economic analysis of a biomass gasification power plant dealing with forestry residues blends for electricity production in Portugal. Journal of Cleaner Production 2019:212:741-753. https://doi.org/10.1016/j.jclepro.2018.12.054

[16] Zhu Y., et al. Techno-economic analysis for the thermochemical conversion of biomass to liquid fuels. United States Department of Energy, 2011. https://doi.org/10.2172/1128665 
[17] Michailos S., Parker D., Webb C. A techno-economic comparison of Fischer-Tropsch and fast pyrolysis as ways of utilizing sugar cane bagasse in transportation fuels production. Chemical Engineering Research and Design 2017:118:206-214. https://doi.org/10.1016/j.cherd.2017.01.001

[18] Ramirez J. A., Rainey T. J. Comparative techno-economic analysis of biofuel production through gasification, thermal liquefaction and pyrolysis of sugarcane bagasse. Journal of Cleaner Production 2019:229:513-527. https://doi.org/10.1016/j.jclepro.2019.05.017

[19] Rafati M., et al. Techno-economic analysis of production of Fischer-Tropsch liquids via biomass gasification: The effects of Fischer-Tropsch catalysts and natural gas co-feeding. Energy Conversion and Management 2017:133:153-166. https://doi.org/10.1016/j.enconman.2016.11.051

[20] Neuling U., Kaltschmitt M. Techno-economic and environmental analysis of aviation biofuels. Fuel Processing Technology 2018:171:54-69. https://doi.org/10.1016/j.fuproc.2017.09.022

[21] Hamelinck C. N., et al. Production of FT transportation fuels from biomass; technical options, process analysis and optimisation, and development potential. Energy 2004:29(11):1743-1771. https://doi.org/10.1016/j.energy.2004.01.002

[22] Albrecht F. G., et al. A standardized methodology for the techno-economic evaluation of alternative fuels - A case study. Fuel 2017:194:511-526. https://doi.org/10.1016/j.fuel.2016.12.003 